\title{
The Ideal Tenant Mix and Shopping Centre Size for the Proposed Thatchfield Convenience Centre
}

\author{
Ajay K Garg ${ }^{1} \&$ Stewart Steyn ${ }^{2}$ \\ ${ }^{1}$ TUT Business School, 159, Nana Sita Street, Pretoria, South Africa \\ ${ }^{2}$ P O Box 350 Rivonia 2128, South Africa \\ Correspondence: Ajay K Garg, TUT Business School, 159, Nana Sita Street, Pretoria, South Africa. E-mail: \\ gargk@tut.ac.za/akg20055@yahoo.co.in
}

Received: October 11, 2014

Accepted: December 4, 2014

Online Published: December 20, 2014

doi:10.5539/ijbm.v10n1p243

URL: http://dx.doi.org/10.5539/ijbm.v10n1p243

\begin{abstract}
This objective of this study was to find an optimum shopping centre size and ideal tenant mix for the current shopping centres around the proposed Thatchfield Convenience Centre. This was done in order to maximise economic sustainability and return on investment. A mixed-method of study was used, employing mainly interviews and questionnaires for data gathering. After determining the main shopping centre tenant categories, questionnaires determined potential customers' preferences regarding retailers. Residents' demographic profiles were used to compare predicted preferences with those obtained through questionnaires and interviews in order to triangulate results. Architects were then able to apply the findings to conceptualise a possible layout.
\end{abstract}

Keywords: Tenant mix, shopping centre, South Africa, convenience centre

\section{Introduction}

The Thatchfield Residential Estate is situated well in relation to both the N14 and N1 highways, with excellent security and access to facilities like golf, soccer and tennis academies. This residential development was brought into the market in 2003 and is a very successful lifestyle development (Note 1). The existing amenities are very small centres with poor tenant mixes and very few one-stop convenience facilities. The residents of the area do not have a convenient shopping centre in the vicinity. The private school group, Curro, has also just opened a school in the area. The opening of this school resulted in a significant increase in daily traffic. The children in this school are from the Thatchfield Estate as well as the surrounding areas.

Approximately 6200 households wit estimated 16500 people were estimated by Thatchfield Estate developers in the area in 2011. If one works on a realistic 4\% growth per annum as per Urban Studies (2011), one can expect the population size to increase from more or less 17160 people in 2012 to approximately 17846 in 2013. This population size indicates that the catchment area has sufficient people to make a convenience centre viable.

Tenant mix is the relationship between the percentages of different store types in a shopping mall (Dawson, 1983:102). The tenant mix shapes the success of the shopping mall because a proper tenant mix can attract more patrons and thus increase the sales of retailers (Abratt et al., 2001, p. 47). On the other hand, an adverse tenant mix can greatly lower the traffic within the mall, thereby reducing many tenants' sales, increasing vacancies and lowering rents (Alexander \& Muhlebach, 2001, p. 38). This study was motivated by the lack of adequate convenience retail shopping facilities for the residents, comprising Thatchfield Residential Estate, The Reeds, Heuweloord and a small portion of Rooihuiskraal. The site for the proposed shopping centre, as seen in Figure 1 below, is located on the corner of the R55 and Drakensberg Road in Centurion. The Thatchfield Residential Estate is located adjacent to the proposed site on its northern and eastern side. 


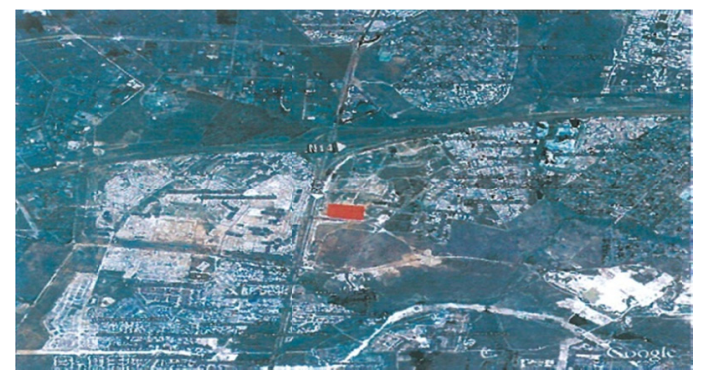

Figure 1. Site indicated in red for proposed Thatchfield convenience centre

Source: Google Earth (2013).

The Centurion and Midrand areas are very strong growth markets, creating new opportunities on a continuous basis. According to Urban Studies (Note 2) (2010), the Centurion node ranks in the top five of the market attractiveness score (MAS) in the country. The catchment area of the centre will include the Thatchfield Residential Estate, The Reeds, Heuweloord and a small portion of Rooihuiskraal. The population figures used are for a $3 \mathrm{~km}$ radius of the proposed site.

This study applied the available statistics of the population demographics of the people as projected by Urban Studies' databank (2010). The study took into consideration the population size, number of households, age groups, culture groups, language groups, employment status, occupation groups, education levels, existing dwelling units, annual household income, living standard measure (LSM) (Note 3), number of residential units planned and average monthly spending on consumer goods of the direct catchment area of the proposed Thatchfield Convenience Centre.

Based on the demographics and preferences of the catchment area, this study proposes a centre that will offer one-stop convenience shopping to potential customers. The centre should comprise a mix that will enable shoppers to do all their everyday shopping at one convenience centre. This study does not include an investigation into the other centres listed and their tenant mixes. The success of the current retailers in the mentioned centres was also not investigated.

In the context of this study, everyday shopping refers to basic groceries, basic pharmaceutical facilities, basic household hardware, pet food specialists, hairdressing facilities, services such as dry cleaners, cellphone shop facilities, video shops with gaming and entertainment facilities, fast foods with one sit-down restaurant, ATM facilities, car wash facilities, a gift and accessories shop, and, given the large number of children and the school adjacent to the proposed site, a specialised book and stationery shop.

\section{Literature Review}

Retail land use constitutes a significant part of the urban environment in all developed, growing and developing countries. In South Africa there are approximately 1619 formal shopping centres ranging from $1000 \mathrm{~m}^{2}$ to almost $150000 \mathrm{~m}^{2}$. These centres represent approximately 17 million square metres of the estimated 37 million square metres of all retail facilities. Shopping centre development in South Africa has accelerated dramatically during the past 25 years (Prinsloo, 2010, p. 1). The retail sector of the local economy represents almost 14\% of the total gross domestic product (GDP) in South Africa, and almost a million people are employed in this sector. The annual sales from all these retail facilities are over R524 billion (Prinsloo, 2010, p. 5).

According to Prinsloo (2010), planned shopping centres can be divided into six types of retail centres. The table below provides a summary. 
Table 1. Showing classification of types of planned shopping centres

\begin{tabular}{ll}
\hline Type and location & Role and function \\
& $\begin{array}{l}\text { Size }\left(\mathrm{m}^{2}\right), \text { number Tenant mix } \\
\text { of stores, Size of }\end{array}$ \\
& land (ha), Radius \\
& of primary trade
\end{tabular}

$(\mathrm{Km})$

Small free-standing and convenience centres

Located on collector streets in suburbs. The average radius of its primary catchment trade area is between $1 \mathrm{~km}$ and $1.5 \mathrm{~km}$.

\section{Neighbourhood centres}

Located on major collector roads in suburbs or township areas offering high visibility and accessibility to passing traffic intended for the suburbs in the immediate vicinity

\section{Community centres}

These centres are located on main arterial roads which are accessible from a number of suburbs located in the area.
The function offered by these centres is mainly express convenience, including a cafe or small food store, take-away foods, DVD stores, banks and ATM facilities.

These centres fulfil a convenience and express role. a reputable, good, attractive and well-known food anchor; the provision of sufficient parking and a very good micro-location,

They offer a large facility within walking distance of a large portion of the community. In many cases, shoppers are prepared to walk to these large centres in order to save on transport costs.

Small regional centres/ large community centres

Good regional accessibility and the site must offer high visibility to the passing traffic and easy accessibility to the residents in the community/region.

\section{Regional centres}

Near a major arterial road, linked to national road offering high accessibly and visibility.

They mainly to satisfy the needs of the broader community and to offer a better tenant mix than the community centres. Some of these centres can also address the needs of a specific market segment. In some cases, especially in more rural areas, these centres play a much larger regional role.

These centres are intended to satisfy the needs of a large primary and secondary catchment area. They are often supported by a strong workforce

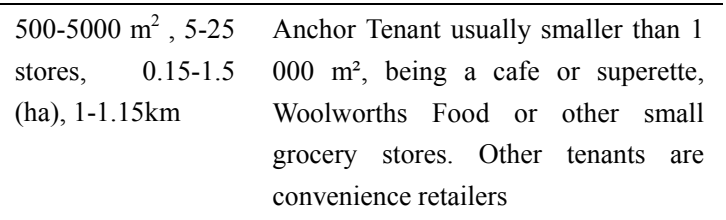

5000-12000 $\mathrm{m}^{2}$

25-50 stores,

Anchor tenant in these centres is

stores, usually larger than $1500 \mathrm{~m}^{2}$, with the

1.5-3.6 ha, 1.5-2 typical tenants being Pick 'n Pay, $\mathrm{km}$ Spar, Checkers, Shoprite and Woolworths Food. The other types of tenant types to be found in these centres are convenience retailers, including a pharmacy, deli, butchery, video store, hairdresser, dry cleaner, liquor store, florist and a hardware store.

$12000-25000 \mathrm{~m} 2$, anchor tenant usually is a supermarket 50-100 stores, that is larger than $2500 \mathrm{~m}^{2}$ and the 3.6-7.5 ha, 2.5-3 tenants are convenience retailers such $\mathrm{km} \quad$ as a pharmacy, deli, butchery, video store, hairdresser, dry cleaner, liquor store, florist and a hardware store. National clothing stores, boutiques, shoe shops and some other comparative shops will also be part of this mix. Restaurants, take-away facilities and services like medical facilities, banks and cinemas might also be part of the mix. in the immediate vicinity. They offer a wide entertainment component to attract people, especially during the
25000-50000 m2, The anchor tenant would be a large 75-150 stores, supermarket of bigger than $4000 \mathrm{~m}^{2}$. 7.5-15 ha, $3-5 \mathrm{~km}$. Other tenants as part of this mix would include convenience retailers, major national anchor clothing stores like Edgars, Woolworths, Mr Price, boutiques, shoe shops, restaurants and take away facilities, entertainment such as cinemas and services such as medical facilities and banking facilities

50000-100000 $\mathrm{m} 2$, In many cases the anchor tenants here 150-250 stores, are one or two large supermarkets. 15+ ha, $5-8 \mathrm{~km} \quad$ Both will be larger than $3500 \mathrm{~m}^{2}$. Other tenants forming part of the mix will include convenience retailers, clothing anchor stores, boutiques, shoe shops and other related tenants, 
evenings, and children during the

holiday periods. fast food outlets and restaurants, entertainment facilities such as cinemas, electronic games and arcades, and other services such as medical facilities, banks, cellphone service centres and office functions. The focus on tenant mix is on comparative and destination shopping in clothing and household goods.
Super-regional centres

Similar to regional centres for the whole metropolitan area - a large region - as well as for national and international tourists. Most small regional centres in a particular city fall in the catchment area of a super-regional centre
These centres provide retail facilities
$>100000 \mathrm{~m} 2$, more than $250,10 \mathrm{~km}$ or more
It has the widest possible tenant mix with at least six anchor tenants, which include grocery stores, clothing stores, household goods and entertainment. The main focus of this type of centre is to offer a wide range of entertainment facilities and the latest trends in all retail products and categories.

Source: Prinsloo (2010).

\subsection{Tenant Mix}

The literature on tenant mix can roughly be divided into two parts. The first part focuses on the question of how to attract the largest possible number of customers to a shopping centre to spend their money there. This question is related to the competitive position of the shopping centre in the area. The second part deals with the question of how to tempt customers to visit all parts of the centre. If customers walk through the entire shopping centre, the probability that they will spend money increases. Based on their knowledge of how to attract customers to a shopping centre and how to get them walking through the entire centre, designers, developers, and managers try to optimise the selection and special configuration of tenants in a shopping centre (Borgers et al., 2010, pp. 377). However, the attractiveness of shopping centres is at least partially related to the composition of the tenant mix (Teller \& Reuterer, 2008, p. 128).

Yeates, Charles and Jones (2001, p. 466) show that the closure of a department store, a typical anchor tenant in a shopping centre, usually has a negative impact on, especially, the performance of the stores located closest to it. In addition, Mejia and Eppli (1999, p. 23) conclude from their analysis of retail sales in a large number of shopping centres that large speciality retailers may increase the sales of small speciality retailers selling similar merchandise.

Bruwer (1997, p. 164) introduced a practical empirical research methodology to determine a new shopping centre's tenant mix before any construction actually begins. He proposed a consumer-preference weighting methodology based on three factors. Respondents were first requested to identify their preferred main tenant categories from a list. Secondly, respondents were requested to rank order their preferred tenant categories. Then they were asked to indicate the likelihood that they would do their shopping at their preferred tenants, should those tenants indeed be present at the new shopping centre. These factors were consolidated into a single composite tenant choice index. Finally, respondents were requested to indicate which shops, institutions or services they preferred to have in the new centre (Borgers et al., 2010, p. 379).

Unfortunately, there is no tested model for predicting the extent of the tenant mix at a shopping mall. To date, tenant mix schemes have merely been a qualitative description formulated purely by practical experience or by trial and error, and then learned by adapting to the environment of the mall. Such an adoption process is often painstaking, and the knowledge gained has not yet been generalised for future use. For example, the Institute of Real Estate Management (1990, p. 78) is of the opinion that there is no single optimal tenant mix for shopping malls, since the tenant mix of an individual mall should be tailored to meet specifications like location, size, demographic profile of the catchment area and consumer needs. Similarly, Casazza and Spink (1985, p. 94) posited that a proper tenant mix for one mall could be a mistake for another mall.

According to Berman and Evans (1995, p. 305), a planned shopping centre consists of a group of architecturally unified commercial establishments built on a site, designed and operated as a unit, based on "balanced tenancy", 
and surrounded by parking facilities. The size and mix of stores should relate to the trade area being served. Quite simply, a good tenant mix, as explained by McCollum (1988, p. 17), refers to having a variety of stores that work well together to enhance the performance of the entire centre as well as performing successfully as individual businesses (Greenspan, 1987, p. 27). Most shopping centre owners believe that there is an optimum tenant mix of stores for their centre; one that creates synergistic advantages (Silverman, 1992, p. 60). Too often, owners are more concerned with return on investment and which tenant can pay the most rent than on the more important tenant composition and who is the best for the centre (Sullivan \& Adcock, 1988, p. 92). Tenant mix is an important key to the success of a shopping centre. Rules dictating the ideal tenant mix are still based on assumptions about consumer preferences and consumer behaviour. However, research into consumers' tenant mix preferences seems to become more prominent in this context (Borgers et al., 2010, p. 377). According to Bean et al. (1988, p. 2), the concept of the ideal tenant mix has not been formulated, but Greenspan (1987, p. 27) is of the opinion that it can be done through intensive market research and common sense.

According to Kaylin (1973, p. 46), an ideal tenant mix strives to achieve a balanced diversification of shops in the centre by offering a wide range of products and services; a specific image for the centre; maximum sales potential in the set trade area; a synergy between the satellite tenants (tenants other than the anchor tenants); a logical layout of shops; a pleasant shopping environment; enough variety to create the maximum attractiveness to the population of the set trade area and maximum return on investment.

Dawson (1983, p. 86) states that tenant mix considerations revolve around two major questions: the number, nature and size of the outlets in the centre, and the placement of these outlets relative to each other and to the points of entry into the complex.

This comprises following well-known rules of thumb, namely:

- $\quad$ place the magnet stores at opposite ends of the mall and line the intervening space with smaller outlets;

- $\quad$ ensure that the main entrances and anchor stores are sufficiently far apart to pull shoppers past the unit shops;

- avoid cul-de-sacs if possible, as they inhibit the free flow of customers;

- place service outlets on the side malls close to the entrances and exits;

- $\quad$ keep pet shops and dry cleaners away from food shops, and food shops separate from outfitters; and

- $\quad$ achieve an even distribution of shoppers in multi-level centres through judicious placement of escalators and eating facilities and the manipulation of the floor at which shoppers enter the complex (Gruen, 1973, p. 45; Beddington, 1982, p. 62; Abratt et al., 1985, p. 21; Sim \& Way, 1989, p. 6).

\subsection{The Importance of Tenant Mix}

The marketing and financial success of a shopping centre depends on many factors. Among the main success factors suggested in previous studies are tenant mix, the quality of location and accessibility, catchment size and quality, car parking provision, internal layout, and convenience. The combination of all these factors will have a bearing on whether or not a developer or landlord will be successful in marketing the centre to both potential tenants and potential consumers. Perhaps the most important of these is the tenant mix. The term "tenant mix" refers to a combination of factors, including the proportion of space or number of units occupied by different retail/service types, as well as the relative placement of tenants in the centre (Kirkup \& Rafiq, 1994, pp. 29). It is widely recognised that the tenant mix of a shopping centre is critical for the parties concerned - consumers, retail tenants and the developer or landlord.

Strong tenants and early lettings are also critical to a centre's financial success. The developer or landlord is seeking an immediate return from early tenants to help pay the organisation's mortgage debts, as well as long-term secure income from well-covenanted tenants who offer good prospects for turnover growth and therefore for rental growth. Pre-lettings to appropriate anchor tenants are particularly important, since they help developers attract funding, set the tone for a centre and encourage leasing commitment from other retailers. Some developers also incorporate a proportion of smaller retailers to add variety and help built a differentiated image to attract customers (Kirkup \& Rafiq, 1994, pp. 30).

Clearly, in all shopping centres the developer should ensure that the number of empty units and tenant failures is minimised. Vacant premises are more noticeable in closed centres, imply failure to a shopper, hinder footfall and synergy and have a significant negative impact on marketing and financial success. 


\subsection{Mall Configuration}

The most common configurations for shopping centres are linear. Parking is provided at the rear, at the sides or in front. Commonly, most or all of the space around a shopping centre will be devoted to parking. The presence of two anchor stores, placed at opposite ends of the centre, is typically considered optimal so that they will draw customer traffic through the centre. A large linear centre, such as a regional centre, will have separated anchors, for example, the principal anchors in the middle with two smaller anchors at the ends (Darlow, 1972, p. 45; Northern \& Haskoll, 1997, p. 96; Beddington, 1982, p. 29; Mulvihill 1992, p. 87). Regional and super-regional centres almost always have a central courtyard area reserved for food services, and this area is normally contained in the centre of the mall.

\subsection{The Importance of Convenience}

A collated definition from the Collins, Oxford and Webster dictionaries explains convenience as that which is easy to use, favourable to comfort or saving of trouble. As such, convenience occurs when the barriers to the undertaking of an activity are reduced or eliminated. In the context of retailing, these barriers are referred to as costs (Downs, 1961, p. 6; Bender, 1967, p. 24). In patronising a retail centre, the consumer must content with special, temporal and effort costs (Reimers \& Clulow, 2004). Retail centre convenience is therefore determined by all attributes of a retail centre that influence the special, temporal and effort costs (Reimers \& Clulow, 2004, p. 207).

The reasons for the growing importance of shopping convenience are as numerous as they are varied. Rising levels of consumer awareness, affluence and mobility have helped create a more discerning consumer, and so have social trends such as increasingly individualistic lifestyles and the growth of non-traditional households. Factors such as time scarcity, the changing role of women and the increasing number of male shoppers have also combined to create a generation of consumers that will no longer tolerate inconvenient centres. And, despite their opposing nature, longer working hours and an increasing leisure orientation have also had an influence on consumers' desire for convenience (Reimers \& Clulow, 2004, p. 208).

\subsection{Shopping Centre Size, Attractiveness and Atmosphere}

Sets of retail outlets located in a nearby geographical area are referred to as retail agglomerations or retail clusters (Berman \& Evans, 1995, p. 56). Teller and Reuterer (2008, p. 127 define retail agglomerations as “...a cluster of stores within a clearly defined spatial area. Despite the heterogeneity of agglomeration formats they are often characterised as being either the product of an explicitly planned process or are considered to have emerged incrementally over time".

Whether or not such sites are established through planned agglomerations such as shopping centres or through unplanned agglomerations such as shopping streets, both consumers and retailers can benefit and realise synergetic effects from this phenomenon (Ghosh, 1986, p. 108).

The reasons for better shopping experiences at a convenience centre than at single stores could be, among others, easy accessibility, parking facilities, orientation systems, a broad variety of shops, atmospheric stimuli or entertainment facilities (Kim, 2002, p. 595).

\subsection{Shopper Behaviour and Preferences}

A key issue for shopping centre developers is ensuring that each mall in their portfolio maintains relevance with key target customer segments. Retailers and developers know that mall patronage is determined by customer satisfaction with the mall shopping experience (Jackson et al., 2011, p. 18).

Shopping malls contribute more significantly to business than do traditional markets, which are viewed as a simple convergence of supply and demand. Shopping malls should attract the right buyers and sellers and induce customers, providing them with enough time, through the close proximity to each other of many divergent shops, to make choices and to enjoy recreational shopping (Rajagopal, 2008, p. 1).

\subsection{Conclusion}

Planned shopping centres are classified in six main categories. Right tenant mix for a shopping centre is necessary to get maximum return on investment. Strong tenants and early lettings are critical to a centre's financial success. Unfortunately, there is no tested model for predicting the extent of the tenant mix at a shopping mall. With such an adhocracy perceived by practitioners, the optimisation of the tenant mix has not been studied scientifically. The answer must be related to the size of the mall because tenant mix, shop size and abundance of retailers in each tenant category are all inextricably intertwined. Mall configuration, convenience, shopping centre size, attractiveness and atmosphere, shopper behaviour and preferences are some of the important factors 
that contribute to the success of a shopping centre.

\section{Research Methodology}

Based on the above the main question for study was: What is the ideal tenant mix and shopping centre size for the proposed Thatchfield Convenience Centre?

\subsection{Methodology}

This study made use of interviews with shopping centre developer, Retail Africa, and Thatchfield Estate developer. In addition, questionnaires pertaining to options for selecting preferred tenants in the given retail categories were distributed in order to collect data. The study population consisted of the primary catchment area, which included the Thatchfield Residential Estate, The Reeds, Heuweloord and a small portion of Rooihuiskraal. The population figures used were for a $3 \mathrm{~km}$ radius of the proposed site. In order for the researcher to obtain information on the retailers preferred by shoppers, questionnaires were distributed randomly in Thatchfield Estate and the surrounding neighbourhoods that also form part of the centre's potential catchment area. Given that the population size in the catchment area is round 17846 people, only a random sample was possible. In this case, the researcher randomly distributed 100 questionnaires in the Thatchfield Estate, as well as randomly distributing 100 more in the other neighbourhoods forming part of the population. Of the 200 questionnaires randomly distributed, 100 completed questionnaires were returned to the researcher for analysis.

In order to obtain accurate and reliable information in the demographics of the catchment area, it was preferable that all inhabitants be included in the sample population. The required information was gathered by means of questionnaires and Urban Studies' databank.

\subsection{Data Collection}

The following data-gathering methods and sources were used in this study:

- $\quad$ Existing statistics

- Standardised interviews with Thatchfield Estate developer, and interviews with the two leasing directors at Retail Africa Property Developers,

- Questionnaires were distributed to 100 residents of the catchment area who lived outside Thatchfield Estate and 100 residents of Thatchfield Estate itself in order to obtain information regarding their preferred retailers. A total of 100 completed questionnaires were returned to the researcher, which is a $50 \%$ participation rate.

- Urban Studies databank and population study;

- Various websites;

- Google Earth;

- $\quad$ Site visits;

- $\quad$ Area drive-around.

\subsection{Data Analysis}

Table 1 reflects the number of households and number of people in the direct catchment area of a $3 \mathrm{~km}$ radius of the proposed site. The table also illustrates the population growth when calculated at $4 \%$ growth per annum as per Urban Studies (2011) field survey.

Table 2. Total population and number of households in direct catchment area

\begin{tabular}{cll}
\hline Area (3 Km Radius) & Number Of People in the Area & Number of Households in the Area \\
\hline Total currently 2011 & 16500 & 6500 \\
$+4 \%$ growth 2012 & 17160 & 6760 \\
$+4 \%$ growth 2013 & 17846 & 7030 \\
\hline
\end{tabular}

Source: Urban Studies field survey (2011) projected for 2011-2013.

Figure 2 indicates the direct catchment area of the proposed site. Areas that are included consist of the Thatchfield Residential Estate, The Reeds, Heuweloord and a small portion of Rooihuiskraal. 




Figure 2. Thatchfield (3 km radius)-Proposed Thatchfield convenience centre

Source: Google Earth (2013).

Figure 3 indicates the areas included within a much smaller $1.5 \mathrm{~km}$ radius of the proposed site.

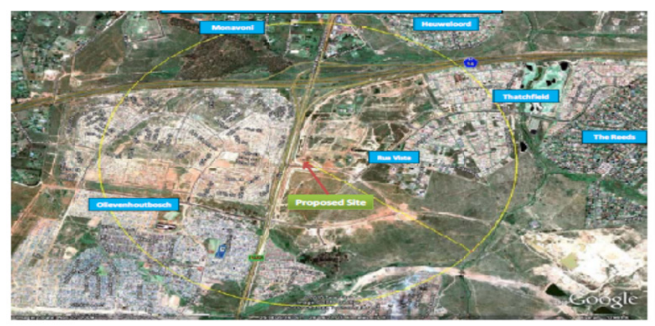

Figure 3. Thatchfield (1.5 km radius) - proposed Thatchfield convenience centre

Source: Google Earth (2013).

\subsection{Socio-Economic and Demographic Profile}

Mainly one resource was used to obtain a better understanding of the socio-economic and demographic profile of this area, namely a study undertaken by Urban Studies (2011) in this area. Their information is based on a survey conducted at households in the catchment area. The samples are representative of the total catchment potential market within a $3 \mathrm{~km}$ radius of the proposed site.

The population in the area represents a young profile, with persons under 19 representing 34\%, persons aged 20-34 representing $31 \%$, persons aged $35-54$ representing $29 \%$, and only $5 \%$ of the population representing 55 -year-olds and older persons. This indicates that this is a rapidly developing area.

A developer or landlord should therefore look at the age groups in the catchment area and look for tenants that will cater for the younger market with family-orientated activities. It is evident that the majority of the studied population is white, at $55 \%$, with a strong black representation at $36 \%$. Only $7 \%$ of the people are Asian and a mere $3 \%$ are Coloured.

This is valuable information when looking at the planned tenant mix, and the developer or landlord should take this into consideration in order to cater for the right population groups. It is also important that the anchor tenants have access to this information, as it will help them to stock and cater for the correct and intended target markets.

When correlating, the results indicate that the most common languages spoken are Afrikaans at $45 \%$, Sotho and Zulu (African) at $27 \%$, English at $26 \%$ and other languages are spoken by only $1 \%$ of the population.

This information is important and tenants should be aware of these results. Both tenants and the landlord could make use of this information by catering in the right way for the language groups in the catchment area. The landlord could, for instance, ensure that all directions and signs cater for all language groups intended to visit the centre. Tenants could cater for these markets by using the relevant languages to market their products and also to employ staff from the relevant language groups in order to adequately cater for the intended market.

The majority of the adult population (74\%) is employed at and only $6 \%$ is unemployed. Twenty percent of the population is not economically active, which means that they are school pupils, students or retired. This indicates 
that the study population consists mainly of working people.

This information could also be useful to both the retailers and the landlord. Seeing that most of the residents of the catchment area are employed, the centre's trading hours could be and discussed for optimal convenience to all. Most of the people will be at work during the day, so the centre will be relatively quiet. Peak times will therefore be early mornings and late afternoons when residents pass to and from work. The small number of residents who are not at work during the day could be catered for during quieter hours of the day. Retailers could even consider introducing specials and reduced prices during these times in order to increase the foot count to the centre.

The majority of the study population (59\%) represents white collar workers. Blue collar workers comprise $18 \%$ of the population and low-skilled workers represent $23 \%$ of the population. This is a clear indication that most of working people in the area are well-skilled, but the considerable number of unskilled workers should not be disregarded.

The occupation groups give retailers an idea of the spending power of the area and the landlord could use this information to look for suitable tenants to cater for the needs of these intended customers.

The employment sectors represented by the working population are community sector $(26 \%)$, financial and insurance sector $(20 \%)$, wholesale and retail sector $(12 \%)$, manufacturing sector $(10 \%)$, transport sector $(8 \%)$, construction (4\%) and agriculture (2\%), with the electrical and the mining sector representing only $1 \%$ of the study population.

This information is interesting but is not of any real practical use to either the tenants or the landlord involved in this development.

The population in the study area displays a well-educated profile $77 \%$ of the study population has matric or a higher qualification, $16 \%$ of the population has some secondary education and a very small number of residents of the study area have no schooling - a mere $3 \%$ of the study population. This information, too, is interesting but it will not affect the tenant mix or the stock that retailers should carry.

The majority of the dwelling units are houses, which represent $85 \%$ of the dwellings of the study population, with the rest of the residents living in informal dwellings, townhouses and small houses in backyards. This means that most of the inhabitants of the study area are financially capable of owning or leasing a house, which places them in a stable environment.

The average monthly household income in the area is between R24 000 and R28 000. This seems to validate the findings, namely that $85 \%$ of the population could afford owning or leasing a house.

Household income information is very important to the landlord for determining the preferred tenant mix as well to the tenants involved. Household income is of importance to retailers in that this could help them decide what stock in which price ranges to have in their shops.

Seventy percent of the study population falls in the very strong living standard measure (LSM) 10 category and the rest of the population is dispersed in other LSM categories. This is an indication of strong buying power in the immediate study area.

This indicates that the residents of the catchment area are a high income group. This will determine the planned tenant mix put together by the landlord and also help the tenants involved determine stock and prices to cater accurately for the direct catchment area.

\subsection{Existing Surrounding Retail Facilities}

Annexure 1 illustrates the existing retail facilities in a $5 \mathrm{~km}$ radius of the proposed shopping centre. The listed centres may be considered as direct competition to the proposed centre. These were taken into account in the surveys, studies and recommendations of this study.

\subsection{Retailers Preferred by Residents of the Catchment Area}

The main categories of convenience shopping centres were identified in the questionnaires and participants were given a number of options in these categories to select their preferred retailers.

The summary of the questionnaire data analysis results (annexure 2) shows that the preferred retailers correlate with the income and LSM groups that reside in the direct catchment area. Regarding the preferred anchor tenants, which are Pick 'n Pay and Woolworths, followed by Spar with slightly fewer votes, these preferred retailers generally cater for and are popular with higher LSM and income groups. Checkers, who received only $14 \%$ of the votes, is seen as a lower income group LSM. Seventy percent of the study population falls in the very high 
LSM 10 group, which explains the large number of votes for Pick 'n Pay, Woolworths and Spar, who cater for the higher LSM categories.

With the preferred retailers in the other tenant categories the same pattern can be seen as with the food anchors. Residents chose the more upmarket and specialised retailers. In some of the categories, such as other anchors, cellphones, veterinary shops and books and stationery, where product prices are generally the same and very competitive, it seems that participants preferred the more well-known retailers.

Looking at specifically the banks, the choice of bank also ties in very accurately with the income groups in the direct catchment area, with the four major national banks, namely FNB, ABSA, Nedbank and Standard Bank, who cater for the higher LSM groups in the market, achieving almost the same number of votes. On the other hand, Capitec and African Bank, catering predominately for the lower LSM groups, obtained far fewer votes.

\section{Conclusions and Recommendations}

The aim of this study was to determine the ideal tenant mix and associated optimum shopping centre size for the envisaged Thatchfield Convenience Centre. Information of this nature is intended to assist the developer in making decisions that maximise economic sustainability and return on investment.

Data collated by Urban Studies offered valuable insight into the essential retail-related characteristics of the broader area and facilitated the identification of the main shopping centre tenant categories. Questionnaires completed by local residents and interviews with key stakeholders revealed customers' preferences regarding retailers, while the demographic mix of the local community also allowed-based on current trends-the determination of customer preferences. The triangulation of these results should lead to credible recommendations.

It is probably useful to reiterate the demographic profile of the catchment area at this point, as established in the study: the consumers are mainly young families, the majority of them with tertiary qualifications and employed full-time. Their average income levels identify them as emerging middle-class households with all the consumer habits associated with that level of disposable income. Fifty-five percent of the households are white, but that proportion is expected to decrease soon, with a concomitant increase in the percentage of black households, in line with the current expansion of the black middle class.

The demographic data, combined with the anticipated impact of existing retail facilities in the direct catchment area, as well as the prevailing shopping patterns and behaviour, underpin the recommendations emanating from this study, as summarised in Table 2 below.

Table 2 in turn, provided Architects to design a hypothetical site development plan for the Thatchfield Convenience Centre, which will unquestionably be a key element in a viability study and business plan.

Table 3. Possible tenants and their individual shop sizes as the recommended tenant mix for the proposed Thatchfield convenience centre

\begin{tabular}{|c|c|c|}
\hline Tenant Category & Possible Tenant & Recommended Size $\left(\mathbf{M}^{2}\right)$ \\
\hline \multirow{4}{*}{ Banks (Atms) } & - $\quad$ Fnb & 7 \\
\hline & - $\quad$ Standard Bank & 7 \\
\hline & - $\quad$ Absa & 7 \\
\hline & - $\quad$ Nedbank & 7 \\
\hline Barber Shop & - $\quad$ Sa Barber & 25 \\
\hline Biltong Shop & - $\quad$ Biltong@Za & 25 \\
\hline Books And Stationery & - $\quad$ Bargain Books & 200 \\
\hline Car Wash & - $\quad$ Sparkling Car Wash & 250 \\
\hline \multirow{2}{*}{ Cellphone And Accessories } & - $\quad$ Vodacom & 85 \\
\hline & - $\quad$ Mtn & 85 \\
\hline \multirow{2}{*}{ Fashion } & - $\quad$ Pick 'N Pay Clothing & 250 \\
\hline & - Ackermans & 300 \\
\hline \multirow{3}{*}{ Fast Foods } & - $\quad$ Steers & 70 \\
\hline & - $\quad$ Debonairs & 80 \\
\hline & - $\quad$ Old Fashioned Fish \& Chips & 65 \\
\hline Florist & - $\quad$ Net Florist & 50 \\
\hline Food Anchors & - Woolworths Food & 1000 \\
\hline
\end{tabular}




\begin{tabular}{|c|c|c|}
\hline & - $\quad$ Pick 'N Pay & 2500 \\
\hline Gifts And Accessories & - $\quad$ Crazy Store & 250 \\
\hline Hair Dresser & - $\quad$ House Of Hair Design & 80 \\
\hline Hardware & - $\quad$ Builders Express & 750 \\
\hline Interior And Furniture & - Weatherlys & 750 \\
\hline Pharmacy & - $\quad$ Clicks & 450 \\
\hline \multirow{2}{*}{ Restaurants } & - $\quad$ Ocean Basket & 350 \\
\hline & - $\quad$ Spur & 450 \\
\hline Services & - $\quad$ Multiserve & 80 \\
\hline Veterinary Shop & - $\quad$ Vet \& Pet & 75 \\
\hline Water Shop & - $\quad$ Oasis Water & 25 \\
\hline Proposed Total Net Lettable Area & & 7273 \\
\hline
\end{tabular}

Although the study used the Thatchfield Convenience Centre as a case study, the methodology and processes described here have broader applications. They enable the formulation of recommendations that make it possible for a developer to plan the physical attributes of an envisaged convenience centre while simultaneously targeting a list of identified desired tenants.

However, it should be emphasised that although the integration of data from diverse sources, as employed in this study, can point a developer in a specific direction, and may even constitute a reasonable assurance of success, a value judgement by a team of experienced assessors is advisable to review the results and refine the recommendations.

Finally, the study also produced a number of topics for further research that could enhance the determination of the ideal tenant mix and associated optimum shopping centre size. The multicultural and multi-ethnic nature of the population in the catchment area offers exciting opportunities for researching the synthesis of diverse tastes and requirements. The income disparity that exists also demands research into the diverse expectations and needs.

\section{Acknowledgments}

The views expressed in this paper are our own and not necessarily of the organisation that the authors are associated with. We like to express our special thanks to Mrs. Eunice Mtshali and her team from library for providing all literature support. We acknowledge the feedback from anonymous referees for their valuable input in improving the quality of this paper.

\section{References}

Abratt, R, Fourie, J. L., \& Pitt, L. F. (1985). Tenant mix: the key to a successful shopping centre. Quarterly Review of Marketing, 15, 19-27.

Alexander, A. A., \& Muhlebach, R. F. (1992). Shopping centre management. Chicago, Ill: The Institute or Real Estate Management of the National Association of Realtors.

Bean, J. C., Noon, C. E., Ryan, S. M., \& Salton, G. J. (1988). Selecting tenants in a shopping mall. Interfaces, 18(2), 1-9. http://dx.doi.org/10.1287/inte.18.2.1

Bender, W. (1967). Consumer purchase costs—do retailers recognize them? In Gist, R. (Ed.), Management Perspectives in Retailing. Sydney: Wiley.

Beddington, N. (1982). Design for shopping centres. London: Butterworths.

Berman, B., \& Evans, J. R. (1995). Retail management: a strategic approach. Englewood Cliffs, N.J.: Prentice Hall.

Borgers, A., Brouwer, M., Kunen, T., Jessurun, J., \& Janssen, I. (2010). A virtual reality tool to measure shoppers' tenant mix preferences. Computers, Environment and Urban Systems, 34(5), 377-388. http://dx.doi.org/10.1287/inte.18.2.1

Bruwer, J. D. W. (1997). Solving the ideal tenant mix puzzle for a proposed shopping centre: a practical research methodology. Property Management, 15(3), 160-172. http://dx.doi.org/10.1108/02637479710169981

Carter, C. C., \& Vandell, K. D. (2005). Store location in shopping centers: theory and estimates. Journal of Real Estate Research, 27(3), 237-265.

Casazza, J., \& Spink, F. H. (1985). Shopping centre development handbook. Washington, D. C.: Urban Land 
Institute.

Darlow, C. (1972). Enclosed shopping centres. London: Architectural Press.

Dawson, J. A. (1972). Retail structure of groups of towns. Regional and Urban Economics, 2(1), $25-65$. http://dx.doi.org/10.1016/0034-3331(72)90003-6

Dawson, J. A. (1983). Shopping centre development. New York: Longman.

Downs, A. (1961). A theory of consumer efficiency. Journal of Retailing, 37, 6-12.

Dukes, H., \& O'Sullivan, R. (2013). Interview: Retail Africa property developers, Centurion. (Notes in possession of author).

Ellis, L. (2011). Interview: Thatchfield Residential Estate developer, Midrand. (Notes in possession of author).

Gosling, D. (1997). Retail trading. In Tutt, P. \& Adler, D. (Eds.), New metric handbook. London: The Architectural Press).

Ghosh, A., \& McLafferty, S. L. (1986). Location strategies for retail and service firms. Lexington, Mass: Lexington Books.

Greenspan, A. (1987). Solving the tenant mix puzzle in your shopping centre. Journal of Property Management, 27-31.

Gruen, V. (1973). Centers for the urban environment: survival of the cities. New York: Van Nostrand Reinhold. Institute of Real Estate Management. Leasing Retail Space. Chicago, IL.

Jackson, V., Stoel, L., \& Brantley, A. (2011). Mall attributes and shopping value: differences by gender and generational cohort. Journal of Retailing and Consumer Services, 18, 1-9. http://dx.doi.org/10.1016/j.jretconser.2010.08.002

Kaylin, S. O. (1973). In-depth analysis for shopping centre game. Shopping Centre World, July: 43-48.

Kim, Y. K. (2002). Consumer value: an application to mall and internet shopping. International Journal of Retail \& Distribution Management, 30(12), 595-602. http://dx.doi.org/10.1108/09590550210453075

Kirkup, M., \& Rafiq, M. (1994). Managing tenant mix in new shopping centres. International Journal of Retail \& Distribution Management, 22(6), 29-37. http://dx.doi.org/10.1108/09590559410070303

McCollum, W. J. (1988). Basic research procedures. In Roca, R. A. (Ed.), Market research for shopping centres (3rd ed.). New York: International Council of Shopping

Meija, L. C., \& Eppli, M. J. (1999). The effect of merchandise space allocation on retail sales in enclosed shopping centre. Journal of Shopping Centre Research, 6, 23-40.

Mulvihill, D. (1992). How Should Stores be Mixed and Matched in Shopping Centers? Urban Land.

Northen, R., \& Haskell, M. (1977). Shopping centres. CALUS, College of Estate Management.

Prinsloo, D. A. (2010). Classification and Hierarchy of Retail Facilities in South Africa. Retrieved from http://www.urbanstudies.co.za/wp-content/uploads/2014/07/New-Retail-Classification-2010.pdf

Rajagopal, D. (2008). Growing shopping malls and behaviour of urban shoppers in Mexico. Unpublished thesis: Graduate School of Administration and Management, Monterrey Institute of Technology and Higher Education, Mexico City Campus.

Rheimers, V., \& Clulow, V. (2004). Retail concentration: a comparison of spatial convenience in shopping strips and shopping centres. Journal of Retailing and Consumer Serices, 11(4), $207-221$. http://dx.doi.org/10.1016/S0969-6989(03)00038-9

Silverman, R. A. (1992). Pitfalls in shopping centre lease use and exclusive clauses. Real Estate Review, 60-62.

Sim, L., \& Way, C. (1989). Tenant placement in a Singapore shopping centre. International Journal of Retailing, 4(3), 4-16.

South African Mall Guide. (2011). Retrieved from http://www.mallguide.co.za

Sullivan, M., \& Adcock, D. (1988). Retail marketing. London: Thomson.

Teller, C., \& Reuterer, T. (2008). The evolving concept of retail attractiveness: what makes retail agglomerations attractive when customers shop at them? Journal of Retailing and Consumer Services, 15(3), 127-143.

Yeates, M., Charles, A., \& Jones, K. (2001). Anchors and externalities. Canadian Journal of Regional Science, 
$4(3), 465-484$.

Notes

Note 1. A lifestyle development is a development catering for a specific lifestyle market.

Note 2. Urban Studies is a property and urban market research organization. Retrieved from http://www.urbanstudies.co.za

Note 3. The term "living standard measure" (LSM) was developed by the South African Advertising and Research Foundation (SAARF). It is a means of segmenting the South African market to group people according to their living standards. LSM is calculated based on the ownership of household assets and monthly income, and is also a standard acronym.

Annexure 1. Existing retail facilities in the direct catchment area

\begin{tabular}{|c|c|c|}
\hline Shopping Centre & Total Gla $\left(\mathbf{M}^{2}\right)$ & Description \\
\hline 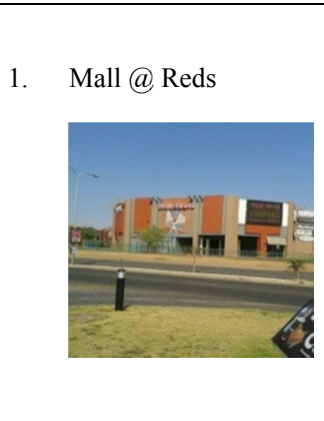 & 50000 & $\begin{array}{l}\text { The Mall @ Reds, Situated On The Corner Of Hendrik Verwoerd \& } \\
\text { Rooihuiskraal Drive, Centurion, Is A Regional Shopping Centre With } \\
\text { Pick 'N Pay And Woolworths As The Main Food Anchor Tenants, } \\
\text { And Edgars And Mr Price As The Main Fashion Anchors. The Mall } \\
\text { @ Reds Has Recently Been Expanded To } 50000 \mathrm{M}^{2} \text {. Even Though } \\
\text { Mall @ Reds Falls Within A Regional Shopping Centre Size, The } \\
\text { Primary Market Considers It A Convenient Type Of Shopping } \\
\text { Facility. This Centre Has A Strong Following And Is Supported Well } \\
\text { By Its Direct Customer Catchment Area Of Rooihuiskraal Because Of } \\
\text { Its Size And National Tenant Mix. }\end{array}$ \\
\hline
\end{tabular}

2. Blu Valley Mall



Blu Valley Mall, Situated On The Corner Of Rooihuiskraal Drive And Bothrill Avenue, Centurion, Is A Convenient Neighbourhood Centre Anchored By Pick 'N Pay And Woolworths Food. The Rest Of The Tenants Are Made Up Of Sit-Down And Fast-Food Restaurants, A Pharmacy And Some Line Shops.

3. The Reeds Spar

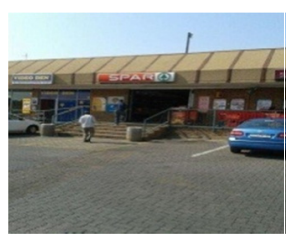

The Reeds Spar Was Recently Revamped And Only Caters For The Residents In Its Immediate Area. This Centre, Situated At 208 Panorama Road, Rooihuiskraal, Comprises Only A Spar, Tops Liquor Store And A Local Pharmacy. The Centre Is Well Supported And Very Busy. Although Very Small, The Spar, Liquor Store And Pharmacy Are Well Stocked To Cater For Their Target Marker.

4. Panorama View

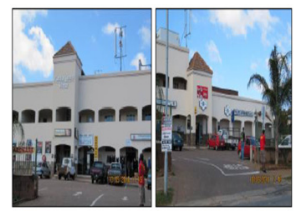

Panorama View Is A Very Small Centre With No National Anchor And Comprises A Liquor Store And A Few Line Shops. It Is Situated At 330 Panorama Road, Rooihuiskraal, And Serves The Direct Market Of The Surrounding Rooihuiskraal. Because Of The Very Limited Tenant Offerings, The Centre Is Very Quiet And Rundown.

5. Celtis Ridge Shopping Centre

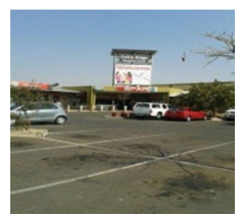

6. Heuwilsig Spar

\section{0}

This Newly Developed Neighbourhood-Type Centre Is Situated On The Corner Of The R55 And N14 Highways And Caters For The Residents In The Immediate Area. 


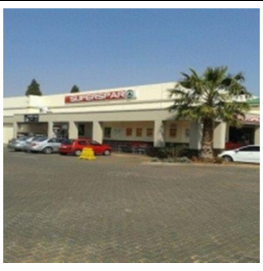

Total $\quad 70513$

Source: SA Council of Shopping Centres - Shopping Centre Directory 2012; photos by the author.

Annexure 2. Questionnaires on preferred retailers: results analysed

\begin{tabular}{|c|c|c|}
\hline CATEGORY & LEADING NATIONAL TENANTS & \multirow{2}{*}{$\begin{array}{c}\text { NUMBER OF VOTES } \\
26\end{array}$} \\
\hline 1. Food anchors & - $\quad$ Pick 'n Pay $26 \%$ & \\
\hline \multirow[t]{4}{*}{ Two may be selected } & - $\quad$ Checkers $14 \%$ & 14 \\
\hline & - Woolworths $27 \%$ & 27 \\
\hline & - Food Lover's Market $8 \%$ & 8 \\
\hline & - $\quad$ Spar $25 \%$ & 25 \\
\hline \multirow[t]{2}{*}{ 2. Other anchors } & - $\quad$ Dis-Chem $66 \%$ & 66 \\
\hline & - $\quad$ Clicks $40 \%$ & 40 \\
\hline \multirow[t]{3}{*}{ 3. Hairdressing } & - $\quad$ Butterflies Hair Salon $10 \%$ & 10 \\
\hline & - House of Hair Design $53 \%$ & 53 \\
\hline & - $\quad$ Gary Rom Hairdressing $37 \%$ & 37 \\
\hline \multirow[t]{3}{*}{ 4. Services } & - $\quad$ Pressed in Time Drycleaners $38 \%$ & 38 \\
\hline & - $\quad$ Multiserv $52 \%$ & 52 \\
\hline & - $\quad$ Levingers Dry Cleaners $10 \%$ & 10 \\
\hline 5. Cell phones & - $\quad$ MTN $23 \%$ & 23 \\
\hline \multirow[t]{5}{*}{ Two may be selected } & - $\quad$ Vodacom $27 \%$ & 27 \\
\hline & - $\quad 8 \mathrm{TA} 7 \%$ & 7 \\
\hline & - Cell C $18 \%$ & 18 \\
\hline & - Virgin Mobile $5 \%$ & 5 \\
\hline & - $\quad$ Altech Auto Page $20 \%$ & 20 \\
\hline \multirow{7}{*}{ 6. Banks Two may be selected } & - $\quad$ FNB $24 \%$ & 24 \\
\hline & - $\quad$ ABSA $16 \%$ & 16 \\
\hline & - $\quad$ Nedbank $21 \%$ & 21 \\
\hline & - $\quad$ Standard Bank $22 \%$ & 22 \\
\hline & - $\quad$ Capitec $15 \%$ & 15 \\
\hline & - African Bank $10 \%$ & 10 \\
\hline & - $\quad$ Bidvest Bank $2 \%$ & 2 \\
\hline \multirow[t]{2}{*}{ 7. Veterinary shop } & - $\quad$ Vet and Pet $72 \%$ & 72 \\
\hline & - $\quad$ Animal Worx $28 \%$ & 28 \\
\hline \multirow[t]{2}{*}{ 8. Car wash } & - $\quad 082$ Car Wash $48 \%$ & 48 \\
\hline & - $\quad$ Sparkling Car Wash $52 \%$ & 52 \\
\hline \multirow[t]{2}{*}{ 9. Gift and accessories } & - $\quad$ Grazy Store $64 \%$ & 64 \\
\hline & - $\quad$ Crafters Market 36\% & 36 \\
\hline \multirow[t]{6}{*}{ 10. Interior and furniture } & - $\quad$ House and Home $28 \%$ & 28 \\
\hline & - Wetherlys $32 \%$ & 32 \\
\hline & - Geen and Richards 5\% & 5 \\
\hline & - $\quad$ The Bed Shop $12 \%$ & 12 \\
\hline & - $\quad$ Dial a Bed $18 \%$ & 18 \\
\hline & - $\quad$ Biggie Best $15 \%$ & 15 \\
\hline \multirow[t]{4}{*}{ 11. Books and stationery } & - $\quad$ PNA $46 \%$ & 46 \\
\hline & - $\quad$ CNA $39 \%$ & 39 \\
\hline & - $\quad$ Books Galore $4 \%$ & 4 \\
\hline & - $\quad$ Bargain Books $11 \%$ & 11 \\
\hline
\end{tabular}




\begin{tabular}{|c|c|c|}
\hline CATEGORY & LEADING NATIONAL TENANTS & NUMBER OF VOTES \\
\hline \multirow[t]{2}{*}{ 12. $\quad$ Florist } & - $\quad$ Local Florist $29 \%$ & 29 \\
\hline & - $\quad$ Net Florist $71 \%$ & 71 \\
\hline \multirow[t]{2}{*}{ 13. Hardware } & - $\quad$ Builders Express $61 \%$ & 61 \\
\hline & - $\quad$ Built It 39\% & 39 \\
\hline \multirow[t]{5}{*}{ 14. Fashion and shoes } & - $\quad$ PnP Clothing 33\% & 33 \\
\hline & - $\quad$ Meltz $10 \%$ & 10 \\
\hline & - Jam Clothing 7\% & 7 \\
\hline & - $\quad$ PEP $21 \%$ & 21 \\
\hline & - $\quad$ Ackermans $29 \%$ & 29 \\
\hline \multirow[t]{4}{*}{ 15. Biltong shop } & - $\quad$ Brooklyn Biltong $36 \%$ & 36 \\
\hline & - $\quad$ Biltong @ ZA 39\% & 39 \\
\hline & - $\quad$ Pioneer Biltong $4 \%$ & 4 \\
\hline & - $\quad$ Biltong Traders $21 \%$ & 21 \\
\hline 16. Restaurants & - $\quad$ Ocean Basket $21 \%$ & 21 \\
\hline \multirow[t]{5}{*}{ Three may be selected } & - $\quad$ Spur $29 \%$ & 29 \\
\hline & - $\quad$ Panarotti’s $18 \%$ & 18 \\
\hline & - Wimpy $7 \%$ & 5 \\
\hline & - $\quad$ Karoo Cattle and Land 7\% & 7 \\
\hline & - $\quad$ Nando's / Barchelos 17\% & 17 \\
\hline 17. Take-aways & - $\quad$ Steers $33 \%$ & 33 \\
\hline \multirow[t]{7}{*}{ Three may be selected } & - $\quad$ Debonairs $22 \%$ & 22 \\
\hline & - $\quad$ Fish Aways 8\% & 8 \\
\hline & - $\quad$ Old Fashioned Fish \& Chips $4 \%$ & 4 \\
\hline & - $\quad$ Fish \& Chip Co 3\% & 3 \\
\hline & - $\quad$ Pizza Perfect $5 \%$ & 5 \\
\hline & - $\quad$ Kung Fu Kitchen 5\% & 5 \\
\hline & - $\quad$ Romans Pizza $20 \%$ & 20 \\
\hline \multirow[t]{4}{*}{ 18. Liquor stores } & - $\quad$ Liquor City $31 \%$ & 31 \\
\hline & - $\quad$ PnP Liquor $29 \%$ & 29 \\
\hline & - Checkers Liquor $16 \%$ & 16 \\
\hline & - $\quad$ Tops (Spar) $24 \%$ & 24 \\
\hline
\end{tabular}

\section{Copyrights}

Copyright for this article is retained by the author(s), with first publication rights granted to the journal.

This is an open-access article distributed under the terms and conditions of the Creative Commons Attribution license (http://creativecommons.org/licenses/by/3.0/). 